head and neck were pressing against the side of the tractor, the force fracturing his cervical vertebral column and resulting in a quadriplegia.

Accidents such as this should be extremely rare if all safety factors are attended to. Legislation requires the power take-off to be covered by a shield whenever the engine is in motion (Agriculture (Power Take-off) Regulations, 1957).

\section{Animals Involved in Accidents}

In the present series $13(10 \%)$ accidents involved farm animals (Table IX). The horse, bullock, and cow were most commonly involved, though the most serious injury was inflicted by a pig.

In 1967 animals accounted for 867 accidents (10\%) to farm workers in England and Wales (Table X). Of these, seven were fatal. Seventy-seven non-fatal and five fatal accidents resulted from attacks by bulls.

Wilson (1966) and Steele-Bodger (1969) have stressed the unpredictable nature of the bull, making it the commonest cause of injury to farm workers among farm animals. Wilson also drew attention to the serious nature of injuries caused by pigs, a fact well illustrated in the present series (Case 42).

\section{Accident Prevention}

Prevention is obviously the only real solution to accidents of any nature. In the United Kingdom regulations have been made under the Agriculture (Safety, Health and Welfare Provi- sions) Act, 1956, to reduce accidents to agricultural workers and children. Wilson $(1966,1969)$ has fully discussed such legislation in the United Kingdom.

Legislation alone, however, cannot prevent accidents, and the final responsibility lies with the farm worker to ensure that all safety precautions are followed; as shown by several of the accidents described in the present series, this is unfortunately not always the case.

I should like to thank Mr. A. G. Murley, Director of the Acciden: Service, Addenbrooke's Hospital, and Mr. D. Rosborough, senior orthopaedic surgical registrar, for considerable guidance and encouragement ; Mr. W. Lewin and Mr. J. Gleave, of the Department of Neurological Surgery, for permission to include patients under their care ; the receptionist, Miss D. Snell, sisters, and nursing staff of the Accident Service for their considerable clerical assistance ; and my fellow accident officers, whose co-operation greatly facilitated this study.

I am also grateful to Mr. G. S. Wilson, Chief Safety Inspector of the Ministry of Agriculture, Fisheries and Food, for his kind assistance in the preparation of this paper.

\section{REFERENCES}

Metropolitan Life Insurance Company (1965). Statistical Bulletin, 46, No. 8

Ministry of Agriculture, Fisheries, and Food (1967). Report of Safety, Health, Welfare, and Wages in Agriculture. London, H.M.S.O. O'Donnell, B. (1967). Fournal of the Irish Medical Association, 60, 47. Rees, W. D. (1965). British Medical fournal, 2, 63.

Steele-Bodger, A. (1969). Annals of Occupational Hygiene, 12, 79. Wilson, G. S. (1966). British Fournal of Industrial Medicine, 23, 1. Wilson, G. S. (1969). Annals of Occupational Hygiene, 12, 129.

\title{
Attenuation of Human Influenza A Viruses
}

\author{
A. S. BEARE,* M.B., M.C.PATH., D.T.M.\&H. ; M. L. BYNOE, $; \dagger$ M.B., D.T.M.\&H.
}

\begin{abstract}
Summary : The attenuation of two human influenza $A$ $S$ viruses has been carried out, using the selection of inhibitor-resistant strains and multiple passages at low temperatures. A virus related to A2/Tokyo/3/67 was obtained in an inhibitor-resistant form. When this was compared with the inhibitor-sensitive strain in a volunteer trial it was relatively non-pathogenic. The second virus, A2/Hongkong/1/68, was subjected to much longer treatment, but nevertheless remained slightly sensitive to serum inhibitor. When given to volunteers it was less pathogenic than before but attenuation was incomplete. A2/Hongkong/1/68 was also modified by passage at low temperatures. Many of these passages are apparently necessary for full attenuation.
\end{abstract}

All attenuated viruses were infective and antigenic.

\section{Introduction}

Live influenza vaccines are used in Russia for mass immunization, and, though protection rates have been variable, there are grounds for confidence in their immunological efficiency, provided that they are effectively administered and their virus

\footnotetext{
* Member, M.R.C. Scientific Staff, Common Cold Research Unit, Salisbury, Wiltshire.

t Dr. By'noe died on 5 June 1969.
}

components are antigenically suitable (McDonala et al., 1962 ; Slepushkin et al., 1967; Beare et al., 1968b, 1969). In the preparation of vaccines our own difficulties have centred on virus attenuation. Initially efforts were made to reduce pathogenicity by simple egg passage, since it had been suggested that the genetic instability of viruses was sufficient to permit this (Burnet and Bull, 1943), and indeed would make the preservation of human infectivity very difficult (Zhdanov, 1967). Experiments showed, however, that, while small changes appeared at first, these were final, and viruses remained substantially unchanged after many egg passages (Beare et al., 1968a).

Methods adopted by Russian workers have also included the testing in volunteers of viruses obtained from patients in the hope that some of them would prove non-pathogenic. These workers concluded from this that viruses resistant to serum inhibitors cause fewer reactions than those which are inhibitorsensitive (Soloviev et al., 1961, 1968 ; Smorodintsev et al., 1965). No publication has, however, appeared which proves that inhibitor resistance and lack of pathogenicity are regularly associated or that when inhibitor-resistant strains are derived from inhibitor-sensitive viruses they are more attenuated for man than their parents. Conventional attenuation methods have also been favoured by Smorodintsev et al. (1965), who have produced vaccines for children by passing viruses at $25^{\circ} \mathrm{C}$. This technique has now been adopted by Maassab $(1967,1969)$, 
who used it successfully to attenuate viruses for mice. In this paper we describe our own manipulations of two recently isolated influenza $\mathrm{A}$ viruses and how these were later shown to be attenuated for volunteers.

\section{Materials and Methods}

\section{Viruses}

The virus A2/England/501/68 was isolated in January 1968 from a throat swab provided by the Public Health Laboratory, Salisbury. It is antigenically similar to A2/Tokyo/3/67. Fluid expressed from the specimen was inoculated amniotically into 10-day embryonated leucosis-free eggs which were incubated at $33^{\circ} \mathrm{C}$. for three days and in which the virus grew with difficulty. Later it was propagated in the allantois and was harvested after 48 hours' incubation at $33^{\circ} \mathrm{C}$. Eighth and ninth egg passages were used as the unmodified inhibitorsensitive seeds in the human trials. The inhibitor-resistant version of this virus was prepared from the eighth egg passage, which was diluted in fluid consisting of phosphate-buffered saline, $10 \%$ nutrient broth, and horse serum (Burroughs Wellcome Horse Serum No. 6 heated at $56^{\circ} \mathrm{C}$. for 30 minutes) in concentrations ranging from 0.005 to $30 \%$. Neomycin was the only antibiotic used in the serial passes.

In the first such passage the virus inoculum consisted of $10^{7.0} 50 \%$ egg-infecting doses $\left(\mathrm{EID}_{50}\right)$, and incubation was carried out at $33^{\circ} \mathrm{C}$. for 48 hours. The eggs were chilled overnight at $+4^{\circ} \mathrm{C}$., and were harvested and tested for haemagglutinin. Positive fluids obtained from the eggs receiving the highest concentrations of horse serum were then passed again by the same technique. The virus content of the inoculum was successively reduced with each passage and the horse serum concentration in the diluent increased, until a virus fully resistant to inhibitor had been obtained. This was achieved after four such passes, the diluent in the final pass consisting of undiluted horse serum. Two further egg passes were made at limit dilution without horse serum. The second of these was used as the inhibitor-resistant strain in human trials. In a subsequent titration this virus was diluted both in broth saline and in horse serum, and the serial dilutions were incubated for one hour at room temperature before they were inoculated into embryonated eggs. The same infectivity titre was recorded by both methods. A conventional haemagglutination-inhibition test showed that the inhibitorresistant virus was not inhibited by undiluted heated horse serum while the inhibitor-sensitive virus was inhibited to a very high titre.
The virus A2/Hongkong/1/68 was received from Dr. H. G. Pereira, of the World Influenza Centre in London. It had had two monkey kidney tissue culture passes and one egg pass, and, after two further egg passes in this laboratory it was given to volunteers (see Table II, trial series A), from whom it was reisolated in leucosis-free eggs, in which it grew readily. Efforts were then made to select an inhibitor-resistant strain by the technique used for A2/England/501/68. This proved very difficult, and after prolonged passage a virus was obtained which was still slightly sensitive to horse serum. This was used as the inhibitor-resistant strain in human trials. Later, both the inhibitor-resistant and inhibitor-sensitive varieties of the virus were passed in eggs at low temperatures. The temperature was first stepped down to $30^{\circ} \mathrm{C}$., and further passes were made by reducing the temperature by $1^{\circ} \mathrm{C}$. steps until the viruses had been adapted to growth at $25^{\circ} \mathrm{C}$. Several passes were made at this temperature and the viruses finally propagated by a limit dilution passage at $33^{\circ} \mathrm{C}$. The latter constituted the low-temperature mutants which were used in the human trials. All incubations at $30^{\circ} \mathrm{C}$. and below were for a 72 -hour period, though it was appreciated that this was usually inadequate for maximum virus yields. No haemagglutinin was detected in the later low-temperature passes, but it was always obtained to high titre after a single pass at $33^{\circ} \mathrm{C}$. The chick embyros tolerated the low temperatures well and mortality was low.

\section{Volunteers}

In most trials two or more viruses were given to groups of volunteers whose susceptibility to infection had been assessed in a preliminary serum haemagglutination-inhibition test. The initial serological status of such groups was invariably similar.

\section{Assessment of Trials}

The behaviour of the viruses in man was judged by the incidence of clinical reactions, excretion of virus on second, third, and fourth days after virus inoculation, and rises of circulating haemagglutination-inhibiting antibody two to three weeks afterwards, according to methods already described (Tyrrell, 1963 ; Beare et al., 1968a).

\section{Results}

When the two strains of A2/England/501/68 were given to comparable groups of volunteers in the same trial, the inhibitor-

TABLE I.-Responses of Volunteers to Inoculation with Inhibitor-sensitive and Inhibitor-resistant Strains of A2/England/501/68 grown at $33^{\circ} \mathrm{C}$.

\begin{tabular}{|c|c|c|c|c|c|c|c|c|c|c|c|}
\hline \multirow{2}{*}{ Trial } & \multirow{2}{*}{$\begin{array}{l}\text { Virus } \\
\text { Passage }\end{array}$} & \multirow{2}{*}{$\begin{array}{c}\text { Sensitivity of } \\
\text { Virus to } \\
\text { Horse Serum } \\
\text { Inhibitor }\end{array}$} & \multirow{2}{*}{$\begin{array}{l}\text { Virus Dose } \\
\left(\text { EID }_{5}\right)\end{array}$} & \multicolumn{2}{|c|}{$\begin{array}{l}\text { Volunteers' Initial } \\
\text { H.I. Titres }\end{array}$} & \multirow{2}{*}{$\begin{array}{c}\text { Virus } \\
\text { Isolations }\end{array}$} & \multirow{2}{*}{$\begin{array}{l}\text { Antibody } \\
\text { Rises }\end{array}$} & \multicolumn{4}{|c|}{ Clinical Symptoms } \\
\hline & & & & $\leqslant 24$ & $>24$ & & & Severe & Moderate & Mild & Nil \\
\hline $\begin{array}{l}53 \text { (a) } \\
53 \text { (b) }\end{array}$ & $\begin{array}{l}\text { E9 } \\
\text { E8 (E + HS }) 4 \text { E2 }\end{array}$ & $\begin{array}{l}\text { Sensitive } \\
\text { Resistant }\end{array}$ & $\begin{array}{l}10^{5 \cdot 5} \\
10^{5 \cdot 5}\end{array}$ & $\begin{array}{l}6 \\
7\end{array}$ & $\begin{array}{l}2 \\
2\end{array}$ & $\begin{array}{l}7 / 8 \\
6 / 9\end{array}$ & $\begin{array}{l}6 / 8 \\
5 / 8\end{array}$ & $\begin{array}{l}4 \\
0\end{array}$ & $\begin{array}{l}2 \\
0\end{array}$ & $\begin{array}{l}1 \\
3\end{array}$ & $\begin{array}{l}1 \\
6\end{array}$ \\
\hline
\end{tabular}

Symbols used in Tables I-III are as follows: $E=$ Egg pass. $(E+H S)=$ Egg passage in presence of heated horse serum. HU $=$ Human passage. Mk $=$ Passage in monkey kidney tissue culture.

Grading of symptoms has been described by Tyrrell (1963). The different parts of numbered trials (a, b, etc.) were performed at the same time. Numerators are numbers of responses, denominators numbers of specimens available for testing.

TABLE II.-Responses of Volunteers to Inoculation with Inhibitor-sensitive and Inhibitor-resistant Strains of A2/Hongkong/1/68 grown at $33^{\circ} \mathrm{C}$.

\begin{tabular}{|c|c|c|c|c|c|c|c|c|c|c|c|c|c|}
\hline \multirow{2}{*}{$\begin{array}{c}\text { Trial } \\
\text { Series }\end{array}$} & \multicolumn{6}{|c|}{$\begin{array}{l}\text { Sequence of Passages of Laboratory } \\
\text { Strain of A2/Hongkong } / 1 / 68^{*}\end{array}$} & \multirow{2}{*}{$\begin{array}{l}\text { Sensitivity of } \\
\text { Virus to } \\
\text { Horse Serum } \\
\text { Inhibitor }\end{array}$} & \multirow{2}{*}{\begin{tabular}{|l} 
Virus \\
Isolations
\end{tabular}} & \multirow{2}{*}{$\begin{array}{l}\text { Antibody } \\
\text { Rises }\end{array}$} & \multicolumn{4}{|c|}{ Clinical Symptoms } \\
\hline & HU & $\mathbf{E}$ & $(\mathrm{E}+\mathrm{HS})$ & $\mathrm{E}$ & $(\mathrm{E}+\mathrm{HS})$ & $\mathbf{E}$ & & & & Severe & Moderate & Mild & Nil \\
\hline $\begin{array}{l}\mathbf{A} \\
\mathbf{B} \\
\mathbf{C}\end{array}$ & $\overrightarrow{1}$ & $\overline{1}$ & $\begin{array}{r}\overline{3} \\
3\end{array}$ & $\overline{1}$ & $\overline{7}$ & $\bar{z}$ & $\begin{array}{l}\text { Sensitive } \\
\text { Partially resistant } \\
\text { Almost resistant }\end{array}$ & $\begin{array}{c}3 / 5 \\
10 / 15 \\
9 / 16\end{array}$ & $\begin{array}{c}3 / 5 \\
13 / 15 \\
12 / 16\end{array}$ & $\begin{array}{l}2 \\
4 \\
0\end{array}$ & $\begin{array}{l}1 \\
1 \\
1\end{array}$ & $\begin{array}{l}0 \\
5 \\
5\end{array}$ & $\begin{array}{r}2+ \\
5 \\
10\end{array}$ \\
\hline
\end{tabular}

* Initial passage history, Mk2 E3. Passages then began with that shown in the left-hand column and proceeded in the order shown.

t Not infected.

Grouns of volunteers had similar haemagglutination-inhibition titres at the beginning of the trials (mostly $<6$ ).
Volunteers shown in Tables II and III received $10^{5 \cdot 0}-10^{5 \cdot 6}$ EID $_{30}$ of virus. 
resistant virus was appreciably more attenuated than its parent, though still capable of producing infections and inducing antibody formation (Table I). The inhibitor-sensitive virus had had nine egg passes and its inhibitor-resistant variant 14 , but since past experience had shown that egg passage alone has little effect on the pathogenicity of influenza viruses it is considered that the attenuation of the inhibitor-resistant strain was mainly reflected in its resistance to horse serum inhibitor. The infectivity of the inhibitor-resistant virus was possibly slightly inferior to that of the inhibitor-sensitive virus, but it remained a potentially effective immunizing agent.

Similar experiments with A2/Hongkong/1/68 are summarized in Table II. The inhibitor-sensitive virus was given to five volunteers in September 1968 (trial series A), three of whom had no detectable haemagglutination-inhibiting antibody, while the remaining two had titres of 9 and 24 respectively, presumably as the result of past experience with antigenically related viruses. These two were not infected, but the others experienced symptoms within 24 hours and their subsequent illnesses were similar to clinical influenza. The success in selecting an inhibitor-resistant variant of A2/England/501/68 could not be wholly repeated with A2/Hongkong/1/68. The trial series B was a combination of two trials in which volunteers received a virus which had had three passages in the presence of horse serum but was still inhibited by it to a titre of 120 . Though it produced some unpleasant reactions, even those graded severe had a delayed onset and their duration was shorter than those with the same grading in series A. Efforts were made to abolish the remaining sensitivity to inhibitor, but this did not prove possible, though it was much reduced after a total of 11 passes in the presence of horse serum. This virus was now given to volunteers in two trials (shown together in series C), and there was no doubt that it was much attenuated. Nevertheless, some pathogenicity persisted.

Studies were now made of the effect of low-temperature passages on some of the inhibitor-resistant strains of A2/Hongkong/ $1 / 68$ already selected and on the inhibitor-sensitive virus. The results of inoculating a few of these viruses into volunteers are shown in Table III. A strain which had had eight passages

TABLE III.-Responses of Volunteers to Inoculation with Inhibitorsensitive and Inhibitor-resistant Strains of A2/Hongkong/1/68 Grown at $33^{\circ} \mathrm{C}$. and at Low Temperatures

\begin{tabular}{|c|c|c|c|c|c|c|c|c|c|}
\hline \multirow{3}{*}{$\begin{array}{l}\text { Trial } \\
\text { Series }\end{array}$} & \multicolumn{3}{|c|}{ No. of Virus Passages* } & \multirow{3}{*}{$\begin{array}{l}\text { Virus } \\
\text { Isola- } \\
\text { tions }\end{array}$} & \multirow{3}{*}{$\begin{array}{l}\text { Anti- } \\
\text { body } \\
\text { Rises }\end{array}$} & \multirow{2}{*}{\multicolumn{4}{|c|}{ Clinical Symptoms }} \\
\hline & \multirow{2}{*}{$\begin{array}{c}(\mathrm{E}+\mathrm{HS}) \\
33^{\circ} \mathrm{C} .\end{array}$} & \multicolumn{2}{|c|}{$\begin{array}{l}\text { E (at } \\
\text { Low Tem- } \\
\text { peratures) }\end{array}$} & & & & & & \\
\hline & & $26^{\circ} \mathrm{C}$. & $25^{\circ} \mathrm{C}$. & & & Sev. & Mod. & Mild & Nil \\
\hline $\begin{array}{l}\text { B (I.R.) } \\
\mathbf{C} \text { (I.R.) } \\
\mathbf{D} \text { (I.R.) } \\
\mathbf{E} \text { (I.S.) } \\
\text { F (I.S.) } \\
\text { G (I.R.) }\end{array}$ & $\begin{array}{r}3 \\
11 \\
8 \\
11\end{array}$ & $\begin{array}{l}- \\
6 \\
5 \\
6 \\
6\end{array}$ & $\begin{array}{l}- \\
1 \\
1 \\
6 \\
2\end{array}$ & $\begin{array}{r}10 / 15 \\
9 / 16 \\
8 / 21 \\
8 / 11 \\
6 / 8 \\
5 / 8\end{array}$ & $\begin{array}{c}13 / 15 \\
12 / 16 \\
14 / 20 \\
9 / 11 \\
7 / 8 \\
4 / 8\end{array}$ & $\begin{array}{l}4 \\
0 \\
0 \\
2 \\
0 \\
0\end{array}$ & $\begin{array}{l}1 \\
1 \\
2 \\
2 \\
2 \\
0\end{array}$ & $\begin{array}{l}5 \\
5 \\
4 \\
3 \\
2 \\
4\end{array}$ & $\begin{array}{r}5 \\
10 \\
15 \\
4 \\
4 \\
4\end{array}$ \\
\hline
\end{tabular}

I.R. = Inhibitor resistant. I.S. = Inhibitor sensitive.

*. Initial passage history $M k 3$ HU1 E1.

When viruses were grown with horse serum or at low temperatures they were given a final limit dilution passage in eggs at $33^{\circ} \mathrm{C}$. before being given to volunteers.

with horse serum and one at $25^{\circ} \mathrm{C}$. (trial series D) was not noticeably more attenuated than the final inhibitor-resistant strain which had had 11 passages with horse serum and none at low temperatures (trial series C). Nevertheless it was clear that reducing the temperature of incubation was having an effect, and that viruses could eventually be made wholly avirulent by this means. Trial series $F$ showed that even the inhibitor-resistant strain was much attenuated after six passes at $25^{\circ} \mathrm{C}$. It would, of course, have been experimentally more satisfactory if the mutants could have been compared with the wild virus in simultaneous trials, but the severe clinical symptoms associated with the original A2/Hongkong/1/68 made its continued use impracticable.
A high rate of infection was attained by all the attenuated viruses.

\section{Discussion}

Trials of the kind we have described cannot make use of large numbers of volunteers. This is compensated for by the fact that they are closely supervised and are carried out with considerable precision. Our results were unequivocal and showed that inhibitor-resistant influenza $\mathrm{A}$ viruses are less pathogenic to man than their corresponding inhibitor-sensitive strains, and that they can infect and induce antibody rises. If they can be obtained with ease (Table I), then a rapid and efficient means of attenuation is available. It is, however, evidently necessary that the conversion to inhibitor resistance should be complete and the persistence of even a small percentage of inhibitor-sensitive particles may render a virus too pathogenic for human use (Table II). There is no reason to believe that inhibitor-resistant viruses would not be immunologically effective, since infections by the respiratory route stimulate the formation of local antibodies which are a factor of great importance in protection (Mann et al., 1968 ; Beare et al., 1968b). Our experiments also showed that passages at low temperatures have an effect but that many of them are required for full attenuation. In this connexion it is of interest that Smorodintsev et al. (1965) passed viruses of their adult vaccines 17 to 20 times at $25^{\circ}$ C. to make them suitable for children.

The questions now posed are formidable. Little is known about the nature of inhibitor-resistant viruses or about pathogenic determinants of influenza viruses generally. Inhibitorresistant viruses are known to occur in nature, but most laboratory stocks have been obtained by passing apparently sensitive strains in the presence of horse serum (Choppin and Tamm, 1960a, 1960b ; Choppin et al., 1960 ; Alexandrova, 1962 ; Lief, 1964).

Choppin and his colleagues, in a series of careful experiments, showed that influenza A seeds are generally mixtures of inhibitor-sensitive and inhibitor-resistant particles, and that their characters are determined by the type which predominates. By neutralizing the former with an appropriate inhibitor they were able to produce pure populations of resistant particles. Obtaining pure seeds of inhibitor-sensitive viruses by limit dilution passages was, however, more difficult. These workers also found that inhibitor-resistant viruses were antigenically similar to their inhibitor-sensitive counterparts, that the characters of individual seeds were relatively stable during the course of a few egg passages, that there were no morphological differences between the two types under the electron microscope, that there was no tendency to mutation of one type to the other, and that inhibitor-resistant viruses eluted more rapidly from red blood cells than inhibitor-sensitive viruses. This last observation has since been confirmed by Russian workers (Soloviev et al., 1961, 1968) and by ourselves (unpublished).

Medvedeva et al. (1968) examined their own low-temperature mutants in the laboratory and were able to differentiate "thermophilic" (virulent) and "cryophilic" (avirulent) variants by plaque morphology at different temperatures. In general, however, genetic studies of influenza A viruses are much hampered by their low plaquing efficiency, and mutants are frequently only biologically detectable. Nevertheless, our present study shows that low-temperature passage is an effective means of attenuation and urgently needs to be made more scientific. Whether it will always be possible to strike the right balance between infectivity and attenuation remains to be seen.

We are indebted to Dr. D. A. J. Tyrrell for constant help, advice, and encouragement during the whole of this work. Our thanks are also due to Miss M. D. Turnbull, S.R.N., for help with the clinical 
surveillance, and to the volunteers for their willing co-operation. Miss Pamela Ball provided excellent technical assistance. The unit receives a grant from the World Health Organization.

\section{REFERENCES}

Alexandrova, G. I. (1962). Acta Virologica, 6, 487.

Beare, A. S., Bynoe, M. L., and Tyrrell, D. A. J. (1968a). British Medical Fournal, 4, 482.

Beare, A. S., Hobson, D., Reed, S. E., and Tyrrell, D. A. J. (1968b). Lancet, 2, 418.

Beare, A. S., et al. (1969). fournal of Hygiene, 67, 1.

Burnet, F. M., and Bull, D. R. (1943). Australian fournal of Experimental Biology and Medical Science, 21, 55.

Choppin, P. W., and Tamm, I. (1960a). Fournal of Experimental Medicine, 112,895 .

Choppin, P. W., and Tamm, I. (1960b). Fournal of Experimental Medicine, 112, 921

Choppin, P. W., Tamm, I., and Murphy, J. S. (1960). Fournal of Experimental Medicine, 112, 945.

Lief, F. S. (1964). fournal of Immunology, 92, 286.
Maassab, H. F. (1967). Nature, 213, 612.

Maassab, H. F. (1969). Fournal of Immunology, 102, 728.

Mann, J. J., Waldman, R. H., Togo, Y., Heiner, G. G., Dawkins, A. T., and Kasel, J. A. (1968). Fournal of Immunology, 100, 726.

McDonald, J. C., Zuckerman, A. J., Beare, A. S., and Tyrrell, D. A. J. (1962). British Medical fournal, 1, 1036.

Medvedeva, T. E., Alexandrova, G. I., and Smorodintsev, A. A. (1968). fournal of Virology, 2, 456.

Slepushkin, A. N., Bobyleva, T. K., Russina, A. E., Vitkina, B. S., Ellengorn, N.' S., and Zhdanov, V. M. (1967). Bulletin of the World Health Organization, 36, 385.

Smorodintsev, A. A., Alexandrova, G. A., Chalkina, O. M., and Selivanov, A. A. (1965). In Applied Virology: 1st Annual Symposium, Boca Raton, Florida, 1964, edited by $M$. Saunders and E. H. Lenntte, p. 142. Sheboygan, Wisconsin, Ellis.

Soloviev, V. D., Neklyudova, L. I., and Orlova, N. G. (1968). Voprosy Virusologii, 13, 396. In Russian. English summary.

Soloviev, V. D., Orlova, T. G., Porubel, L. A., and Vasilieva, I. N. (1961). Voprosy Virusologii, 6, 684. English translation.

Tyrrell, D. A. J. (1963). American Review of Respiratory Diseases, 88, No. 3, part 2, p. 128.

Zhdanov, V. M. (1967). In Proceedings of First International Conference on Vaccines against Virel and Rickettsial Diseases of Man, Washington 1966, p. 9. Washington, Pan American Health Organization.

\title{
Postural Influence on Maternal Capillary Oxygen and Carbon Dioxide Tension
}

\author{
C. K. ANG,*; T. H. TAN,*; W. A. W. WALTERS, † M.B., M.R.C.o.G., PH.D. ; C. WOOD, $\ddagger$ M.B., F.R.c.s., F.R.c.o.g.
}

\begin{abstract}
Summary : The effect of posture on maternal capillary $\checkmark$ blood $\mathrm{Po}_{2}$ and $\mathrm{Pco}_{2}$ was studied in pregnant and non-pregnant women. There was a significant decrease of $\mathrm{Po}_{2}$ (mean $13.0 \mathrm{~mm}$. $\mathrm{Hg}$ ) and significant decrease of $\mathrm{Pco}_{2}$ (mean $2.4 \mathrm{~mm} . \mathrm{Hg}$ ) when pregnant women sat up, but these changes did not occur in the non-pregnant. These findings may be relevant to debate on the optimum posture for labour.
\end{abstract}

\section{Introduction}

In the sixteenth century patients were delivered in an obstetric chair (Cutter and Viets, 1964). Today the African Bantu still gives birth in the sitting position, and this has led to the suggestion that this position be adopted for childbirth. Obviously, when bearing down, gravity would be an additional force when the patient was in the erect or sitting position. The major disadvantage of an upright posture during delivery would be the difficulty the accoucheur would have in gaining access to the site of delivery. The effect of posture on maternal blood oxygen levels has not been studied, though the lowest mean arterial blood $\mathrm{PO}_{2}$ reported in pregnant patients was in subjects studied in the dorsal position, while the highest mean arterial blood $\mathrm{PO}_{2}$ was in patients studied in the sitting position (Rooth and Sjöstedt, 1962 ; Stenger et al., 1964). As asphyxia is a common cause of stillbirth any factor influencing maternal oxygenation deserves investigation, and the present experiments were designed to study the effect of posture on maternal blood oxygen levels.

* Fifth-year Monash University Medical Student.

† Senior Lecturer.

$¥$ Professor.

Department of Obstetrics and Gynaecology, Monash University, Queen Victoria Hospital, Melbourne, Victoria, Australia.

\section{Material and Methods}

Ten patients between the 35th and 40th weeks of their pregnancy were studied, four of them being primigravidae. Their ages ranged from 17 to 35 years. The control group consisted of 10 non-pregnant women of similar age and parity. None of the patients were obese or were taking drugs, and none had evidence of cardiovascular or pulmonary disease. The experimental procedure was explained to each patient, who had previously volunteered for the study.

The basis of the experimental procedure was a series of observations made on each patient in two different positions: supine with one pillow under the head and two pillows under the calf, and sitting with the body slightly forward of the vertical position. After the patient had been in the supine position for 20 minutes the pulse and blood pressure were recorded and a blood sample was taken; this procedure was repeated five minutes later. The patient then changed her position to the erect one, and after 10 minutes two more sets of measurements (pulse, blood pressure, and blood sample) were taken with a five-minute interval between them.

The blood pressure was recorded with a sphygmomanometer, and care was taken to maintain the arm cuff at the level of the heart during all recordings. Each blood pressure measurement represented the mean of three readings taken at one-minute intervals.

The blood sample was collected from the ear lobe after it was made hyperaemic with tetrahydrofurfuryl nicotinic acid ester paste. Capillary blood $\mathrm{Po}_{2}$ and $\mathrm{PcO}_{2}$ measured from samples taken from the ear lobe have been shown to compare favourably with arterial blood oxygen and carbon dioxide levels (Siggaard-Andersen, 1967; Koch, 1968). Comparison of capillary and arterial blood in our laboratory has produced results similar to those of Koch, the mean arterial/capillary 